\title{
FEWER COMPLAINTS, MORE SATISFACTION: CYPRUS V. TURKEY
}

\author{
Frederike Kollmar ${ }^{*}$ \\ Jan Martin Hoffmann
}

\section{Keywords}

European Court of Human Rights, Inter-State Complaint Procedure, Just Satisfaction

\section{Introduction}

On 12 May 2014, the European Court of Human Rights (ECtHR or the Court) awarded, for the first time in its history, just satisfaction under Article 41 of the European Convention on the Protection of Fundamental Rights and Freedoms ${ }^{1}$ (ECHR or the Convention) within the context of an inter-state complaint procedure under ECHR Article 33. In the case of Cyprus $v$ Turkey 2014, ${ }^{2}$ the Court's Grand Chamber ruled that Turkey has to pay EUR 90 million to Cyprus in respect of the non-pecuniary damage suffered by the relatives of 1,456 missing persons (€30 million) as well as the enclaved Greek Cypriot residents of the Karpas peninsula (€60 million). The sums are to be distributed by the Cypriot Government to the individual victims under the supervision of the Committee of Ministers of the Council of Europe (CoM).

The decision of the Court is based on its principal judgment on the merits of 10 May 2001 (Cyprus v Turkey 2001). The Grand Chamber found numerous violations of obligations of the ECHR and its protocols by Turkey in regard to the above mentioned groups, arising out of: the Turkish military operations in the northern part of the island in July and August 1974; the continuing division

\footnotetext{
Frederike Kollmar is Research Assistant and $\mathrm{PhD}$ candidate at the Chair of Public International and European Law (Prof Dr V Epping), Leibniz University of Hannover; Dr Jan Martin Hoffmann is Head of Division at the Federal Office of Administration, Germany. The authors would like to thank the editors for their valuable comments and suggestions on an earlier draft. Any views expressed are personal.

1 European Convention on the Protection of Fundamental Rights and Freedoms, 04 November 1950, ETS No 5.

2 Cyprus v Turkey (just satisfaction) [2014] ECtHR 25781/94.
}

Copyright $\odot$ the Author(s).

This work is licensed under a Creative Commons Attribution-NonCommercial-NoDerivs 3.0 License. 
of the territory of Cyprus; and the activities of the so-called 'Turkish Republic of Northern Cyprus'. In its 2001 judgment, the Court had held unanimously that the application of ECHR Article 41 was not ripe for deliberation and had adjourned consideration of the issue accordingly. ${ }^{3}$ The procedure concerning the execution of the principal judgment is currently pending before the CoM.

One might argue that the CoM's obvious difficulty tackling this politically delicate situation encouraged the Court to take this new step. The distribution mechanism in the operative part of the judgment puts a certain pressure on the CoM and can be understood as a shift of power to the ECtHR. Thus, Cyprus $v$ Turkey 2014 not only clarifies the range of application of ECHR Article 41, but also has strong implications for the Convention system's institutional balance. Whether it really marks the beginning of 'a new era in the enforcement of human rights' ${ }^{4}$ remains to be seen. It certainly adds a new item to the Court's tool kit, not only from an institutional point of view, but also in the context of the workload the ECtHR faces.

Several questions as to the applicability of ECHR Article 41 in inter-state proceedings in general, and in the specific case at hand, fell to the Court to be decided. This article focuses on the innovative statements in the judgment and relevant separate opinions, and seeks to put these in a broader perspective.

\section{Applicability of ECHR Article 41 in Inter-State Cases under ECHR Article 33}

\subsection{Remedies under the Convention}

Under the Convention, the ECtHR has no explicit competence to order remedial measures. The Court has repeatedly emphasized that its judgments are essentially declaratory in nature, ${ }^{5}$ confined to legal findings of observance or breach of the Convention. Under ECHR Article 46(1) (in conjunction with ECHR Article 19), the High Contracting Parties undertake to abide by the Court's final judgments in any case to which they are parties. ECHR Article 46(2)-(4) confers the supervision of the execution of judgments upon the CoM. According to ECHR Article 41, however, the Court may, under certain circumstances, award just

\footnotetext{
3 Cyprus v Turkey (merits) [2001] ECtHR, 25781/94, operative part VIII.

${ }^{4}$ Cyprus v Turkey (just satisfaction) [2014] ECtH, 25781/94 (Joint Concurring Opinion of Judges Zupančič, Gyulumyan, David Thór Björgvinsson, Nicolaou, Sajó, Lazarova Trajkovska, PowerForde, Vučinić and Pinto De Albuquerque).

${ }^{5}$ Verein gegen Tierfabriken Schweiz v Switzerland (No 2) [2009] ECtHR 32772/02, para 61.
} 
satisfaction to the injured party. This is the case if the Court finds a violation of the Convention or its additional Protocols, and if the internal law of the High Contracting Party only provides for partial reparation. From a historical view, it should be noted that former ECHR Article 50 (now ECHR Article 41), as well as former ECHR Article 24 (now ECHR Article 33), have been-unlike the individual complaint procedure-compulsory provisions of the Convention from the time of its entry into force. ${ }^{6}$

As a general principle, only an obligation of result follows from the duty to abide by the final judgments. It is up to the state to decide how the judgment is executed as long as the violation is ended and the consequences are erased. These rather narrow effects have been broadened by the Court to enhance its effectiveness. Should the Court classify the circumstances as appropriate, it would indicate (or even order) individual or general measures to provide redress. ${ }^{7}$ Furthermore, the Court developed the pilot judgment procedure based on ECHR Article 46(1) to tackle systemic problems in a state's legal system. ${ }^{8}$ The concept of a more extensive interpretation of ECHR Article 41 therefore follows and expands upon an already established path.

\subsection{Applicability of ECHR Article 41 to Inter-State Complaint Procedures under ECHR Article 33}

The Court firstly recalls, when examining the applicability of ECHR Article 41 to inter-state complaint procedures under ECHR Article $33,{ }^{9}$ that until now it had dealt with this issue only once in the case of Ireland $v$ United Kingdom. ${ }^{10}$ However, there was no necessity to explore this question in that case as the applicant government had expressis verbis declared not to raise any claims for monetary compensation..$^{11}$ The Court then moves to a historical approach, reiterating that the general logic of the rule of ECHR Article 41 was not substantially different from the logic of reparations in public international law. ${ }^{12}$

${ }^{6}$ ECHR Article 41 differs by wording, yet not by substance from former ECHR Article 50.

7 D Harris, M O’Boyle, E Bates \& C Buckley, Law of the European Convention on Human Rights (2 ${ }^{\text {nd }}$ edn, 2009) 862.

8 See e.g. D Haider, The Pilot-Judgment Procedure of the European Court of Human Rights (2011) 167.

9 Cyprus v Turkey (just satisfaction) [2014] ECtHR 25781/94, paras $39 \mathrm{ff}$.

${ }^{10}$ Ireland $v$ United Kingdom [1978] ECtHR 5310/71.

11 Ibid, para 245.

${ }^{12}$ Cyprus v Turkey (just satisfaction) [2014] ECtHR 25781/94, para 40. 


\subsubsection{ECHR Article 41 as Lex Specialis}

While the Court acknowledges the specific nature of ECHR Article 41 as lex specialis in relation to the general principles of international law, ${ }^{13}$ it nevertheless invokes general rules on international liability, namely the right to adequate reparation for the breach of a commitment undertaken by a government; ${ }^{14}$ the right of an 'injured state' to obtain compensation from the state that has committed an internationally wrongful act for the damage caused by it; ${ }^{15}$ and the power of an international court or tribunal with jurisdiction in respect of a claim of state responsibilities to award compensation for the damage suffered. ${ }^{16}$ It does so by means of interpreting ${ }^{17}$ the provision of ECHR Article 41 and its applicability to the present inter-state complaint procedure.

As Koskenniemi has pointed out in the ILC 'Report on the Fragmentation of International Law, ${ }^{18}$ there are two ways of understanding the rule of lex specialis. A special rule may be either considered an application of a common standard in a given circumstance or it may be considered a modification, setting aside or overruling of the latter. ${ }^{19}$ While it can be stated that the law of state responsibilities in principle remains applicable to human rights treaties, ${ }^{20}$ there are in general, and regarding the ECHR in particular, certain differences to the concept of remedies in international law. The special character of an international obligation undertaken in a human rights instrument, such as the ECHR, is distinct from ordinary treaties in international law, which merely set out reciprocal rights and obligations between the contracting states. ${ }^{21}$ By

${ }^{13}$ Ibid, para 42.

${ }^{14}$ Factory at Chorzów (1928) PCIJ Ser A No 17, p 17.

${ }^{15}$ Gabč́kovo-Nagymaros Project (Hungary v Slovakia), ICJ Reports 1997 p 7, 81.

${ }^{16}$ Fisheries Jurisdiction Case (Federal Republic of Germany v Iceland), ICJ Reports 1974 p 175, 32.

${ }^{17}$ Cf H Birkenkötter, 'Some Reflections on the ECtHR's First Award on Inter-State Satisfaction' (Verfassungsblog, 15 May 2014) <http:// www.verfassungsblog.de/en/reflections-ecthrs-firstaward-inter-state-atisfaction/\#.U_GtnoCSyEw> [accessed 18 August 2014]; but cf H P Aust, 'Der EGMR als regionaler IGH? Entschädigung und Bestrafung im Staatenbeschwerdeverfahren' (Verfassungsblog, 14 May 2014) <http://www.verfassungsblog.de/der-egmr-als-regionalerigh-entschaedigung-und-bestrafung-im-staatenbeschwerdeverfahren/\#.U_GwAoCSyEw> [accessed 18 August 2014].

${ }^{18}$ M Koskenniemi, Fragmentation of International Law: Difficulties Arising from the Diversification and Expansion of International Law, Report of the Study Group of the International Law Commission, ILC Ybk 2006 II(2); cf UN Doc A/CN.4/L.682, 35, para 56.

19 Ibid, para 57.

${ }^{20}$ D Shelton, Remedies in International Human Rights Law (2 ${ }^{\text {nd }}$ edn, 2005) 50.

${ }^{21}$ W Karl, 'Just Satisfaction in Art 41 ECHR and Public International Law: Issues of Interpretation and Review of International Materials', in A Fenyves et al (eds.), Tort Law in the Jurisprudence of 
contrast, the ECHR is focused on the rights of individuals. Under the ECHR, the inter-state complaint procedure constitutes no exception. This tool is not traditionally seen as serving a claimant of reciprocal rights under the ECHR in pursuance of their individual national interest, but rather as a method of collectively guaranteeing the compliance with the rights and freedoms set forth in the instrument and its additional protocols. ${ }^{22}$

Article 55 of the ILC Draft Articles on the Responsibility of States for Internationally Wrongful Acts ${ }^{23}$ expresses that, to the extent that special rules and procedures exist, these rules override the general rules of international law. In the commentaries, ECHR Article 41 is expressly mentioned as an example of such a rule of lex specialis. ${ }^{24}$ However, it is the special rule that determines to what extent the general rule is displaced ${ }^{25}$ and a full derogation of general legal consequences of wrongful acts-in the sense of the concept of 'self-contained regimes ${ }^{26}$ - cannot arise from the ECHR. ${ }^{27}$ The Court has repeatedly highlighted that:

[the provisions of the Convention] cannot be interpreted and applied in a vacuum. Despite its specific character as a human rights instrument, the Convention is an international treaty to be interpreted in accordance with the relevant norms and principles of public international law, and, in particular, in the light of the Vienna Convention on the Law of Treaties (...) ${ }^{28}$

Matters of treaty interpretation are governed by the Vienna Convention on the Law of Treaties ${ }^{29}$ (VCLT), namely Articles 31-33, which are considered to

the European Court of Human Rights (2011) paras 4-8.

${ }^{22}$ Austria v Italy [1961] 788/60, RDC, (1962) 4 ECHR Ybk, 116, 138.

${ }^{23}$ Draft Articles on the Responsibility of States for Internationally Wrongful Acts, ILC Ybk 2001/II(2), 26, Art 55.

${ }^{24}$ Commentary to the Articles on the Responsibility of States for Internationally Wrongful Acts, ILC Ybk, 2001/II(2), 31, 140, Art 55, para 3.

${ }^{25}$ Karl, above n 21, para 4/50; see also Amoco International Finance Corporation v Iran (1987-II) 15 Iran-US CTR 222.

${ }^{26}$ Cf B Simma, 'Self-contained regimes' (1985) 16 NYIL 111, 117, $129 \mathrm{ff}$.

${ }^{27}$ Karl, above n 21, para 4/53.

${ }^{28}$ Cf Cyprus v Turkey (just satisfaction) [2014] ECtHR 25781/94, para 23; see also M Villiger, 'Articles 31 and 32 of the Vienna Convention on the Law of Treaties in the Case-Law of the European Court of Human Rights', in J Böhmer et al (eds), Internationale Gemeinschaft und Menschenrechte: Festschrift für Georg Ress zum 70. Geburtstag (2005) 317ff (with further references).

${ }^{29}$ Vienna Convention on the Law of Treaties, 23 May 1969, 1155 UNTS 331. 
be declaratory of customary international law. VCLT Article 31(1) stipulates that treaty terms are to be interpreted in accordance with their ordinary meaning in their context and in the light of the treaty's object and purpose. According to VCLT Article 31(3)(c), relevant rules of international law applicable in the relations between the parties shall be taken into account together with the context.

\subsubsection{Interpretation of ECHR Article 41}

The Court applies the VCLT rules of interpretation when elucidating its understanding of the terms 'injured party' in ECHR Article 41. It first reiterates, by means of grammatical interpretation, that the term 'party' has to be understood as one of the actual parties to the proceedings before the Court. The Court sets aside the argument of the respondent government that the wording of Rule 60(1) of the Rules of Court implies that only individual applicants are entitled to request the award of just satisfaction, for this provision is of lower hierarchical value. Furthermore, Rule 60(1) only reflects the obvious reality that, until now, awards have been granted solely to individual applicants to the Court. The Court then distinguishes the present case from the aforementioned traditional understanding of the main purpose of the inter-state complaint procedure by outlining that, in casu, the applicant government denounces violations by another contracting state of the basic human rights of its nationals. Here the Court draws parallels between the present case, the individual-complaint procedure under ECHR Articles $34 \mathrm{ff}$, and the instrument of diplomatic protection as part of the general law on state responsibility. The Court cites Articles 1 and 19 of the Draft Articles on Diplomatic Protection $^{30}$ as developed by the International Law Commission and refers to the International Court of Justice's judgment in the Diallo ${ }^{31}$ case. $^{32}$

Diplomatic protection can be described as 'the procedure employed by the state of nationality of the injured person to secure protection of that person and to obtain reparation for the internationally wrongful act inflicted. ${ }^{33}$ It is questionable whether or not this reference is well founded. ${ }^{34}$ Under traditional

\footnotetext{
${ }^{30}$ Draft Articles on Diplomatic Protection, ILC Ybk 2006 II(2), cf UN Doc A/61/10, 16, Arts 1 and 19.

${ }^{31}$ Ahmadou Sadio Diallo (Republic of Guinea $v$ Democratic Republic of the Congo), Preliminary Objections, ICJ Reports 2007 p 582, 599; in passim, Compensation, ICJ Reports 2012 p 324, 344.

${ }^{32}$ Cyprus v Turkey (just satisfaction) [2014] ECtHR 25781/94, para 46ff.

${ }^{33}$ Draft Articles on Diplomatic Protection, ILC Ybk 2006 II(2), cf UN Doc A/61/10, 21, 24, para 2.

${ }^{34}$ See I Risini, 'Can't get no just satisfaction? The Cyprus v. Turkey judgment of the European Court of Human Rights (CJICL Blog, 23 May 2014) <http://cjicl.org.uk/2014/05/23/cant-getjust-satisfaction-cyprus-v-turkey-judgment-european-court-human-rights/> [accessed $18 \mathrm{Au}-$
} 
international law, the instrument of diplomatic protection is perceived-by legal fiction-as asserting the right of the applicant state to ensure, in the person of its subjects, respect for the rules of international law. ${ }^{35}$ However, today it is understood to also assert the rights of a state's injured nationals. ${ }^{36}$ Nevertheless, the system of diplomatic protection leaves it up to the respective state of nationality to exercise the protection; it is a right of the state, and although the individual is directly affected, he or she only plays an indirect role. ${ }^{37}$ This contrasts with the special nature of the Convention as a human rights instrument, containing rights for the individual that can be invoked both individually and-after the exhaustion of local remedies-directly by any person claiming to be a victim of a wrongful act imputable to a state party. Therefore, under the Convention there is no need for the legal fiction still necessary in general international law for the claims of diplomatic protection.

Here it could be argued that the lex specialis rule applies insofar as to derogate from this legal fiction. Under the Convention, it is the individual that is injured by a violation of one or several Convention rights and should therefore, under the Convention, be the beneficiary. Interestingly, however, the Court does not mention Article 48(1)(a) of the ILC Draft Articles on Responsibility of States ${ }^{38}$ in this context, which provides that a state other than the injured state is entitled to invoke the responsibility of another state, if the 'obligation breached is owed to a group of States including that State, and is established for the protection of a collective interest of the group'. This rule can be read as a right to exercise protection on behalf of an injured individual who is not a national. It would, therefore, cover the aforementioned traditional understanding of the instrument of inter-state complaint procedures under the Convention as a tool of collective guarantee, which is not limited to invoking rights of the applicant states' nationals. Combined with the fact that the Court speaks of the individual as 'primarily' being injured, it could be speculated that the Court supports a 'Vattelian-approach' regarding the question of applicability of ECHR Article 41 to inter-State cases: Vattel had argued that 'whoever ill-treats a citizen indirectly

\footnotetext{
gust 2014].

35 Cf V Künzli, 'As If: The Legal Fiction in Diplomatic Protection' (2007) 18 EJIL 37, 38 ff.

${ }^{36}$ Draft Articles on Diplomatic Protection with commentaries, ILC Ybk 2006 II(2), cf. UN Doc. A/61/10, p 20, 25, para 3; C F Amerasinghe, Diplomatic Protection (2008) 73 ff.

${ }^{37} \mathrm{~J}$ Dugard, 'Diplomatic Protection', in R Wolfrum (ed), Max Planck Encyclopedia of Public International Law (online edn, 2009) MN13, 68.

${ }^{38}$ Draft Articles on the Responsibility of States for Internationally Wrongful Acts, ILC Ybk 2001/II(2), 26, Art 48.
} 
injures the State, which must protect that citizen. ${ }^{39}$ As will be shown, when applying Article 41 in the present case, the Court rejects such a reading of the decision.

\section{Application in the Present Case}

Once the question of applicability in general was answered, it was up to the Court to establish the criteria according to which just satisfaction can be awarded in an inter-state case. Resorting to an almost classic technique of international tribunals, the Court does not determine precise and specific requirements, but states that this has to be assessed on a 'case-by-case basis. ${ }^{40}$ This certainly allows for adjustments and further developments of more or less any kind; on the other hand, a lot of academic work will be needed as there are only very few inter-state cases.

The Court holds that there can be no automatic award of just satisfaction. As to the case before it, the ECtHR refers to the given situation and takes into account:

[I]nter alia, the type of complaint made by the applicant government, whether the victims of violations can be identified, as well as the main purpose of bringing the proceedings insofar as this can be discerned from the initial application to the Court. ${ }^{41}$

Obviously, this wording leaves a wide discretion to the Court. A closer analysis of these criteria illustrates that the type of complaint the Court refers to alludes to the difference between general issues like systemic problems or administrative practices on the one hand, and the concrete violation of Convention rights by the respondent state on the other. In the former category, the Court indicates that it might be inappropriate to award just satisfaction. ${ }^{42}$ The latter can be compared to situations resulting in individual complaints and, accordingly, the application of ECHR Article 41 is well founded. ${ }^{43}$ The rationale supporting this view is basically that these proceedings serve as a replacement

\footnotetext{
${ }^{39}$ E de Vattel, Le Droit des Gens ou Principes de la Loi Naturelle vol I, Book II (1758) para 71.

${ }^{40}$ Cyprus v Turkey (just satisfaction) [2014] ECtHR 25781/94, para 43.

${ }^{41}$ Ibid.

${ }^{42}$ Ibid, para 44.

${ }^{43}$ Ibid, para 45.
} 
of one or more individual complaints. This might be a hint towards the real background of the judgment.

The identification of the victims of the violation is a convincing criterion. When inter-state complaint procedures are aimed at the award of just satisfaction, they only serve as a placeholder or a vehicle to facilitate individual protection that normally would stand on its own. ${ }^{44}$ It is not directed at any loss by the applicant state; it is only intended to be used to make good the losses of individuals. Therefore, the Court rules that while the sum awarded as damages is granted to the applicant state, the amount of money depends on the number of individuals and the violations they suffered. What is more, the applicant state is obliged to ensure transfer of the respective amount to each individual through an effective mechanism. ${ }^{45}$ This feature can be found in Article 19 of the Draft Articles on Diplomatic Protection, too, but there it is only formulated as a recommendation and not an obligation. Here the Court rejects the aforementioned Vattelian-approach and stresses the idea that when just satisfaction is awarded as a result of inter-state complaint procedures, the applicant state merely plays the role of a transmission belt for what could as well be proceedings started by individual persons. ${ }^{46}$ This stands in line with the special character of the ECHR as an effective human rights instrument as well as the subsidiarity of the Convention system. The latter is underlined by placing the burden on the applicant state in relation to the individualisation of the victims and the specification of the respective sum to be distributed.

This part of the Court's reasoning could be considered flawed to a certain extent. If the just satisfaction that is claimed represents the aggregate satisfaction sums for all victims, then the number of victims must be known. It is undisputed that, in the present case, the actual figures are not clearly established and the Court held that awarding a lump sum would be appropriate. However, this result seems acceptable as the amount of damages under ECHR Article 41 is usually fixed on an equitable basis. ${ }^{47}$ Extending this equitable approach without establishing the exact number of beneficiaries does not put the whole idea into question, as it has never been understood as a mathematically precise task rather than an approximation to what could be deemed as 'just'. On the contrary, it fits well

\footnotetext{
${ }^{44}$ Ibid, para 43.

${ }^{45} \mathrm{Ibid}$, paras $58 \mathrm{ff}$.

${ }^{46}$ Ibid, para 46.

${ }^{47}$ Cf F Bydlinski, 'Methodological Approaches to the Tort Law of the ECHR', in A Fenyves et al (eds), Tort Law in the Jurisprudence of the European Court of Human Rights (2011) paras 2/174 ff with further references to the case law.
} 
with the Court's established technique of determining the amount awarded in a discretionary manner.

As regards the third yardstick against which the applicability of ECHR Article 41 is measured, namely the question of the main purpose of bringing the proceedings, curiously the Court does not further elaborate on it. Although it remains unclear what this means exactly, it seems to indicate the introduction of some subjective element, or the construction of a 'will' of the applicant state. Besides any explicit pronouncements during the course of the proceedings, this will be very difficult to detect and establish. It can be understood as a reference to a bona fide element: under certain circumstances, states should be prevented from raising just satisfaction claims that appear prima facie justified.

\section{Further Analysis}

\subsection{Punitive Damages?}

The concurring opinion of Judge Pinto de Albuquerque, joined by Judge Vučinić, provokes an even deeper consideration of what the underlying aim of just satisfaction in inter-state cases is or should be. Is it about making good on incurred losses or is there also an element of prevention and punishment? This question leads to the idea of punitive damages and whether the Court is free to take into account aspects going beyond a narrow interpretation of what just satisfaction can be. For the two concurring judges, the 'punitive nature of this compensation is flagrant. ${ }^{48}$ They make a strong effort to illustrate this argument with extensive theoretical reasoning. Although it is debatable whether or not punitive damages are an acceptable tool for the Court, from our point of view it does not seem to be the case that the amount awarded in the judgment has any punitive character. As stated earlier, the sum has been based on considerations of equity.

According to ECHR Article 41, the competence of the Court to award just satisfaction solely applies where the internal law of the High Contracting Party concerned allows only for partial reparation. This means that just satisfaction is merely intended to serve as a tool for full reparation, i.e. to make good on losses suffered. Furthermore, the Court has consistently rejected claims for punitive

\footnotetext{
${ }^{48}$ Cyprus v Turkey (just satisfaction) [2014] ECtHR 25781/94 (Concurring Opinion of Judge Pinto de Albuquerque, joined by Judge Vučinić) para 13.
} 
damages. ${ }^{49}$ Bearing in mind the innovation the judgment presents, it would not have been recommendable to take even more daring steps in expanding the competences of the Court as it might provoke adversarial reactions by the state parties without any compelling reason.

\subsection{Tackling the Backlog of Cases through the Awarding of Just Satisfaction in Inter-State Complaint Procedures}

\subsubsection{Pilot Judgments}

A dimension of the Cyprus v Turkey 2014 ruling that could easily be overlooked is a certain similarity to the pilot judgment procedure as developed by the Court, on the invitation of the CoM, by interpretation of ECHR Article 46(1). ${ }^{50}$ Pilot judgments allow systemic failures in a state's legal order in contravention of the Convention to be efficiently dealt with by using one individual complaint to decide on a larger number of parallel cases. Despite being more or less generally accepted both by scholars and practitioners, pilot judgments deviate from the principle of individual justice that pervades the Convention system. In an equivalent manner, the awarding of just satisfaction to a large number of victims in one single judgment that stems from a single inter-state procedure does not focus on the individual situations. By its statement that the victims must be identifiable, the Court ensures that the claims do not get out of hand, but still allows for a combined decision on numerous potential applications-in this case a figure of at least four digits.

\subsubsection{Individual Claims on Similar Matters}

Another interesting question tackled in this context is what the findings of the Court in its ruling on just satisfaction mean for potential and pending individual claims regarding the same matters. The Court had stated in the case of Varnava et al $v$ Turkey $^{51}$ that ECHR Article 35(2)(b) and Article 37(1)(c) could not be applied, even though a judgment had been delivered in the inter-state case of Cyprus $v$ Turkey 2001. The Grand Chamber founded its reasoning on a narrow approach to the principle of res iudicata, according to which not only identity of the merits

\footnotetext{
${ }^{49}$ Akdivar et al $v$ Turkey [1996] ECtHR 21893/93, para 38; Orhan v Turkey [2002] ECtHR 25656/94, para 448.

${ }^{50}$ See Haider, above n 8, 134ff.

${ }^{51}$ Varnava et al $v$ Turkey [2009] ECtHR 16064/90, 16065/90, 16066/90, 16068/90, 16069/90, $16070 / 90,16071 / 90,16072 / 90$ and 16073/90.
} 
of the claim, but also of the parties introducing the dispute, is required for the matter to be considered substantially the same:

It [would] therefore not be the case that by introducing an inter-State application an applicant government thereby deprives individual applicants of the possibility of introducing, or pursuing their own claims. $^{52}$

This would clearly speak against an assumption of preclusion of individual claims. Interestingly though, the Court further elaborated this by reasoning that the findings in the inter-state application did not specify in respect of the individuals concerned. ${ }^{53}$ It also took into regard that the Court has the competence in individual applications to issue just satisfaction awards for pecuniary and non-pecuniary damage suffered by individual applicants. ${ }^{54}$ Therefore, it could not be said that the individual applications were precluded as they were considered to give rise to issues and outcomes differing from those of the inter-state case of Cyprus $v$ Turkey 2001. ${ }^{55}$ As this has substantially changed due to the ruling at hand, where the Court awards just satisfaction based on the fact that the individual beneficiaries are at least specifiable, the Court takes the foundation from this reasoning in Varnava et al $v$ Turkey. One could therefore argue that because of the findings of the Court in the present ruling, potential claimants would possibly now be barred from filing their own applications. Those applications already filed could be struck out of the Court's list of pending cases. Insofar as applications of the aforementioned categories are based on the same factual circumstances, a new application would now have to be considered substantially the same as the matter that has already been examined by the Court (cf ECHR Article 35(2)(b)) or that has been solved (cf ECHR Article 37(1)(b)) as part of the inter-state procedure.

Similarities can be drawn to the case of Koç et al $v$ Turkey, where a settlement between Denmark and Turkey had been reached and the Court struck the case out of the list. ${ }^{56}$ However, it should be kept in mind that a reading like this would stand in contradiction with Article 16 of the ILC Draft Articles on Diplomatic Protection, ${ }^{57}$ according to which:

\footnotetext{
${ }^{52}$ Ibid, para 118.

${ }^{53}$ Ibid, para 119; cf Cyprus v Turkey (merits) [2001] ECtHR 25781/94, para 133.

${ }^{54}$ Ibid, para 119.

${ }^{55}$ Ibid.

${ }^{56}$ [2002] ECtHR 40802/98.

${ }^{57}$ Draft Articles on Diplomatic Protection, ILC Ybk 2006 II(2), cf UN Doc A/61/10, 16, Art 16.
} 
The right of States, natural persons, legal persons or other entities to resort under international law to actions or procedures other than diplomatic protection to secure redress for injury suffered as a result of an internationally wrongful act, are not affected by the present draft articles.

Against the background of the Court's findings in Varnava et al $v$ Turkey and its workload, ${ }^{58}$ however, an understanding in the former sense would not only be justifiable from a legal point of view, but also a very welcome, if not necessary, development in order to ensure the effectiveness of the Convention system. By awarding just satisfaction to a large number of individuals through the vehicle of one single judgment based on ECHR Article 41, the Court might move away from an individual approach to just satisfaction to a more constitutional one. ${ }^{59}$ This is consonant with the Court's request to the Cypriot Government to set up an effective mechanism for the distribution of the awarded just satisfaction. ${ }^{60}$ In the future, potential individual claims for satisfaction would then have to be addressed to the Republic of Cyprus, as the matter of just satisfaction is shifted to the national level. This is an outcome that is surely in harmony with the wording of ECHR Article 41, which refers back to the national legal order. ${ }^{61}$ The reaction of the Court could therefore be seen as standing in line with other recent measures in respect to reducing its caseload.

\subsection{Cyprus v Turkey 2014 as an Illustration of the Relationship between the Court and the Committee of Ministers}

The judgment also contains some institutional implications. The Court touches only very briefly upon the role of the CoM in supervising the execution of judgments, ${ }^{62}$ but these short remarks seem to indicate an inter-institutional, quasiconstitutional conflict between the Court and the CoM. Through the vehicle of just-satisfaction proceedings, the Court, many years after the principal judgment,

\footnotetext{
${ }^{58}$ For a further discussion see, R Wolfrum \& U Deutsch (eds), The European Court of Human Rights Overwhelmed by Applications: Problems and Possible Solutions (2009).

${ }^{59}$ P Mahoney, 'Thinking a Small Unthinkable: Repatriating Reparation from the European Court of Human Rights to the National Legal Order', in L Caflisch et al (eds), Liber Amicorum Luzius Wildhaber: Human Rights - Strasbourg Views (2007) 263, 266ff.

${ }^{60}$ See Cyprus v Turkey (just satisfaction) [2014] ECtHR 25781/94, para 59.

${ }^{61}$ See in favour: Mahoney, above n 58, 263, $272 \mathrm{ff}$.

${ }^{62}$ Cyprus v Turkey (just satisfaction) [2014] ECtHR 25781/94, para 27, para 59 and para $62 \mathrm{ff}$.
} 
reopens the case and undertakes to give statements on the (non-)execution of its own judgment. ECHR Articles 46(3) \& (4) empower the Court to interpret its rulings, but only after this task is referred to it by the CoM. Accordingly, the decision lies with this institution and the Court acts as a service provider. In the judgment at hand, the Court modifies this relationship to a certain extent when it changes the benchmark of what the CoM is supposed to supervise. In the principal judgment, the ECtHR held that Turkey acted in breach of several articles of the ECHR, but ordered no specific remedial action to be taken in the operative part of the judgment. Accordingly, there was room for discussing how and when Turkey would abide by the judgment, jeopardizing any effective supervision by the CoM. ${ }^{63}$ Although this remains unchanged, a further, most specific duty is placed upon the Turkish authorities, namely the payment of EUR 90 million to Cyprus as the applicant State. During the supervision of its execution, no sound argument can be brought forward against the payment; non-payment would amount to a flagrant breach of Turkey's obligation under ECHR Article 41. By raising the pressure against the respondent state, the Court also diminishes the margin the CoM enjoys when fulfilling its task under ECHR Article 46(2), resulting in less room for political considerations.

The Court partially steers the CoM's work not only by adding a new operative part that is more precise but also by assigning a whole new specific task to the CoM. More specifically, the Court expressly puts the setting up of an effective mechanism for the distribution of the EUR 90 million by the Cypriot government under the control of the CoM. Possibly as a reaction to the rather ineffective supervision process (thus far), it also includes a time-limit of eighteen months for the distribution and, therefore, for a reaction of the CoM. The latter is in a position to alter the time limit but at least it will be compelled to take a stand when the period elapses. It remains to be seen whether this step results in a shift of power from the CoM-which is vested with an almost unfettered discretion as to its supervisory role-to the Court.

\section{Conclusion}

The reviewed judgment has been hailed as 'a new era in the enforcement of human rights' and an 'important step in ensuring respect for the rule of law in Europe', as

\footnotetext{
${ }^{63}$ As the Court stresses, the execution of the principal judgment is still pending before the CoM and that it has not been complied with yet: Cyprus v Turkey (just satisfaction) [2014] ECtHR 25781/94, paras $5 \& 63$.
} 
well as 'the most important contribution to peace in Europe' in the history of the Court. ${ }^{64}$ Despite its innovative approach and the strengthening of the position of the Court as one of constitutional significance, we do not share this euphoria yet. First, the judgment can only be seen as a starting point for a new strand of the Court's jurisprudence, second, a rapid development cannot be expected as the inter-state complaint procedures form only a very small number of cases brought to the Court. Such complaints are often seen as an 'antagonism' towards another European partner and therefore stand not only at variance with the Council of Europe's underlying 'ethos of cooperation and interdependence, ${ }^{65}$ but also with the limitation set forth by the Court in the present case for applicability of ECHR Article 41. It operates only for complaints that are motivated by good faith.

\footnotetext{
${ }^{64}$ Cyprus v Turkey (just satisfaction) [2014] ECtHR 25781/94 (Joint Concurring Opinion of Judges Zupančič, Gyulumyan, David Thór Björgvinsson, Nicolaou, Sajó, Lazarova Trajkovska, PowerForde, Vučinić and Pinto De Albuquerque).

${ }^{65}$ S Greer, The European Convention on Human Rights (2006) 24.
} 